\title{
Growth and Nutrient Utilization of Pangasianodon hypophthalmus (Sauvage, 1878) fed with Graded Level of Zinc
}

\author{
Dilip Kumar Singh ${ }^{1}$, Mukesh Kumar ${ }^{2}$, Amit Ranjan, Uday Kumar Udit ${ }^{5}$, \\ Bhartendu Vimal $^{3}$, Binay Bhushan Nayak ${ }^{4}$ and Subodh Gupta ${ }^{1^{*}}$
}

${ }^{1}$ Fish Nutrition, Biochemistry and Physiology Division, ${ }^{2}$ Fish Genetics and Biotechnology Division, ${ }^{3}$ Aquatic Animal health management Division, ${ }^{4}$ Fisheries Resources, Harvest and PostHarvest Technology Division, ICAR- Central Institute of Fisheries Education, PanchMarg, Off Yari Road, Mumbai, Maharashtra 400061, India

${ }^{5}$ Fish Genetics and Biotechnology Division, ICAR-Central Institute of Freshwater Aquaculture Kausalyaganga, Bhubaneswar, Odisha 751002, India

*Corresponding author

\section{A B S T R A C T}

Keywords

$$
\text { Zinc }
$$

supplementation,

Pangasianodon

hypothalamus,

SGR, PER, FER,

Calpain activity.

\section{Article Info}

Accepted:

14 May 2017

Available Online:

10 June 2017
A 60-day experiment was conducted to determine the effect of graded levels of dietary Zinc supplementation on growth and nutrient utilization of Pangasianodon hypophthalmus (Sauvage, 1878) fingerlings. Fishes of uniform size (average weight 10.5-11 g) were divided into six experimental groups in triplicates following completely randomized design (CRD). Six isonitrogenous and isoenergetic (30\% Crude protein and $381 \mathrm{kcal} / 100 \mathrm{~g}$ Digestible energy) caseinbased diet were supplemented with 20 (control), 23(T1), 26(T2), 29(T3), 32(T4) and 35(T5) $\mathrm{mg}$ zinc/kg diet respectively were fed to $P$. hypothalamus juveniles for a period of 60 days. The Specific growth rate (SGR), Protein efficiency ratio (PER), and Feed efficiency ratio (FER) were significantly ( $p<0.05)$ higher in the T4 treatment group. Intestinal amylase, gill carbonic anhydrase activities were increased whereas muscle Calpain activity was lowered with increased supplementation level of Zinc in the diets in subsequent treatment groups. Based on our finding it is concluded that dietary Zinc supplementation at $32 \mathrm{mg} / \mathrm{kg}$ diet improves growth performance and flesh quality of $P$. hypophthalmus.

\section{Introduction}

Pangasianodon hypothalamus (Sauvage, 1878 ) is a native catfish of Mekong Delta in Vietnam (Hung et al., 2004), and is widely cultured in earthen ponds in the South-East Asia. This species has a great potential as aquaculture species, as it grows very fast and attains marketable size in very short (6 months) period of culture. In India, the commercial culture of this species is of recent origin. It was transplanted from Thailand into Bangladesh in 1989 (Ahmad et al., 2007), and from Bangladesh, it was introduced into West Bengal, India during 1994-95. Large scale seed production had been carried out since 
then (Chattopadhyay et al., 2002). With the promotion of the species by developmental agencies in India for large-scale aquaculture, there has been tremendous interest shown by the farmers in the country to farm this species.

Mineral requirements are essential for growth and survival of fish as they have a role in macronutrient utilization, nutrigenomic interaction, homeostasis and osmotic balance. Among the trace minerals, Zinc ( $\mathrm{Zn}$ ) has an important role in metabolism. Zinc is one of the most important trace elements involved in animal growth. It is the most widely used metal co-factor of enzymes involved in protein, nucleic acid, carbohydrate and lipid metabolism as well as control of gene transcription and other fundamental biological processes. Daily Zinc requirements in fish vary as a function of age, growing stage, season and reproductive cycle. The main role of Zinc is a co-factor in many enzymatic systems involved in the utilization of almost all nutrients and its essentiality for several biochemical processes (Lall, 2002), make it inevitable to be supplemented in the diet. A dietary input is vital at least in fresh water fish and the requirement levels are between 15 to $30 \mathrm{mg} / \mathrm{kg}$. The Zinc requirement has been estimated at $15-30 \mathrm{mg} / \mathrm{kg}$ feed for rainbow trout, Oncorhynchusmykiss (Ogino and Yang, 1978), and $37-57 \mathrm{mg} / \mathrm{kg}$ feed for Atlantic salmon, Salmosalar (Maage and Julshamn, 1993, Maage et al., 1993). Shim and Lee (1993), reported that Zinc deficient diet causes poor growth rate, low feed efficiency and high mortality in the guppy. Every fish species has its minimum Zinc requirement. The absence of adequate Zinc in the diet causes poor growth and show deficiency symptoms such as erosion of fins, skin and eye cataracts (Ogino and Yang, 1979). Zinc deficiencies in brood stock diets reduce egg production and hatchability. Iron and Copper metabolism in the diet is also influenced by the dietary Zinc supplementation. ZincCopper and Zinc-Iron antagonistic activities were reported for some fishes. Dietary Zinc reduces hematocrit value of channel catfish at higher levels of $\mathrm{Cu}$ intake (Galtin et al., 1989). Strong inverse correlation between dietary Zinc, whole body iron, and whole body Zinc was observed in Nile tilapia (Chen et al., 2001). Similarly higher level of Zinc in diet can cause toxicity to fishes although fish can tolerate high-level Zinc without any adverse effect. Rainbow trout and common carp can tolerate 1,700 to $1,900 \mathrm{mg} \mathrm{Zn} / \mathrm{kg}$ of diet without adverse effect on growth (Jeng and Sun, 1981; Wekell et al., 1983).

Looking into above perspective present experiment was conducted to find the effect of dietary supplementation of the graded level of Zinc on muscle development in $P$. hypophthalmus.

\section{Materials and Methods}

\section{Experimental fish and feeding}

Animals used for the experiment were advanced fingerlings of Pangasianodon hypophthalmus (Sauvage, 1822) with an average weight of 10.5-11.0 g. The fishes were procured from the Indispesca Pvt. Ltd. Aquafarm, Dhasai Dam, Thane, Mumbai. The fishes were transported in the well-aerated syntax tanks. They were carefully transferred to a circular tank $(1000 \mathrm{~L})$.

Two hundred sixteen (216) advanced fingerlings of P.hypophthalmus were randomly distributed in six distinct experimental groups, in triplicates, following a completely randomized design (CRD). The setup consisted of 18 plastic rectangular tubs (200 L capacity) covered with perforated lids. Optimum physico-chemical water quality was maintained throughout the experimental period by following (APHA, 1998). Fish were fed ad libitum twice a day in morning and in the evening. 


\section{Preparation of experimental diets}

Six diets with the graded level of Zinc in different concentrations namely Control (20 $\mathrm{mg} / \mathrm{kg}), \mathrm{T} 1$ (23 mg/kg), T2 (26 mg/kg), T3 (29 mg/kg), T4 (32 mg/kg), T5 (35 mg/kg) were prepared as given in table 1. Purified ingredients such as casein (vitamin-free), gelatin, dextrin, starch, cellulose, carboxymethyl cellulose (CMC), Betaine hydrochloride, Butylated Hydroxytoluene (BHT), cod liver oil, sunflower oil, the vitamin-mineral mixture (Zinc free) and vitamin $\mathrm{C}$ (Roche), were taken for feed formulation. All the ingredients were accurately weighed in a plastic container. Gelatin crystals were mixed in lukewarm water so as to form a jelly, which mixes easily with the other ingredients. The other ingredients were mixed then with the gelatin jelly to form a dough with the addition of tap water. When the dough was formed it was transferred to an aluminium container, which was then placed in a pressure cooker for cooking/ steaming.

The steaming was done for half an hour. The steamed dough was taken out and was cooled further. When the steamed dough was completely cooled, the calculated concentration of the oils, vitamins, and minerals mixture were incorporated in it and mixed well and was pressed through a hand pelletizer to get uniform-sized pellets, which were spread on a sheet of paper and were initially sun dried. After that, the feed was transferred to trays and was kept in a hot air oven overnight for complete drying at 50 $60^{\circ} \mathrm{C}$. After drying the pellets were packed in polythene bags and were sealed airtight and were labeled according to the treatments.

Proximate analysis of the diets and carcass tissues

The moisture content of the experimental diets and carcass tissue (Tables 2 and 3) was determined by taking a known weight of the sample in the petri dish and drying it in a hot air oven at $100-105^{\circ} \mathrm{C}$ till a constant weight was achieved. The nitrogen content of the experimental diets and carcass tissue dried samples were estimated quantitatively by Kjeltec semi-automated system (2200 Kjeltec Auto Distillation, Foss Tecator, and Sweden) using titration as the means for determining nitrogen percentage. Ether extract of dried experimental diets and carcass tissue samples were estimated by Soxhlet apparatus using petroleum ether (Boiling point $40-60^{\circ} \mathrm{C}$ ) as the solvent. Ash content of the experimental diets and carcass tissue was estimated by taking a known weight of dried samples in a silica crucible and placing it in a muffle furnace at $550^{\circ} \mathrm{C}$ for 6 hours. Organic matter of the experimental diets and carcass tissue was calculated by subtracting the ash (\%) from 100. The total carbohydrate (TC) of the experimental diets and carcass tissue was calculated by subtracting the percentage of other nutrients from 100 (Hasting, 1967). Digestible energy of the experimental diets and carcass tissue was calculated as per standard physiological values (Halver, 1976).

\section{Growth parameters}

Sampling for growth was done at every 30 days to assess the body weight of the fishes. Fishes were starved overnight before taking the weight in an electric balance.The growth performance was assessed by using the following formula:

$$
\begin{aligned}
& \text { weight gain }(\%)=\frac{\text { Final weight }- \text { Initial Weight }}{\text { Initial weight }} \times 100 \\
& \operatorname{SGR}(\%)=\frac{\log _{\mathrm{e}} \text { Final weight }- \text { Log }_{\mathrm{e}} \text { Initial weight }}{\text { Number of days }} \times 100 \\
& \mathrm{FCR}=\frac{\text { Food given (Dry Weight) }}{\text { Body Weight Gain (Wet Weight) }}
\end{aligned}
$$


FER $=\frac{\text { Net Weight Gain (Wet Weight) }}{\text { Feed Given (Dry Weight) }}$

PER $=\frac{\text { Net Weight Gain (Wet Weight) }}{\text { Protein Fed }}$

Survival $(\%)=\frac{\text { Total number of harvested animal }}{\text { Total number of stocked }} \times 100$

\section{Enzyme assays}

At the end of the experiment (Control, T1, T2, T3, T4, T5), fishes were collected from each tank and anaesthetized with clove oil (50 $\left.\mu L . L^{-1}\right)$. Fishes were then dissected and the tissues viz., brain, liver, gills, intestine and muscle, were immediately removed. A 5\% tissue homogenate was prepared in chilled $0.25 \mathrm{M}$ sucrose solution by Teflon coated mechanical homogenizer (REMI Equipment, Mumbai, India). The whole procedure was followed in ice-cold condition. Homogenized samples were centrifuged at $8000 \mathrm{rpm}$ for 10 min at $4^{\circ} \mathrm{C}$. The supernatant was collected in glass vials and stored in the deep freezer ($20^{\circ} \mathrm{C}$ ) for enzyme assay. Suitable dilution of the samples was done as and when required.

Protease activity was determined by the casein digestion method as (Drapean, 1976). The enzyme reaction mixture consisted of $1 \%$ casein in $0.05 \mathrm{M}^{\text {Tris }} \mathrm{PO}_{4}$ buffer (pH 7.8) and incubated for $5 \mathrm{~min}$ at $37^{\circ} \mathrm{C}$. Then tissue homogenate was added. Ten minutes later, thereaction was stopped by adding 10\% TCA and the whole content was filtered. The reagent blank was made by adding tissue homogenate just before stopping the reaction and with no incubation. One unit of enzyme activity was defined as the amount of enzyme needed to release acid-soluble fragments equivalent to $\Delta 0.001 \mathrm{~A} 280$ per minute at $37^{\circ} \mathrm{C}$ and $\mathrm{pH} 7.8$.

Amylase activity was assessed following the method of (Rick and Stegbauer, 1974). The reducing sugars produced due to the action of glucoamylase and amylase on carbohydrate was estimated using dinitro-salicylic acid (DNS) method. The reaction mixture consisted of $1 \% \quad(\mathrm{w} / \mathrm{v})$ starch solution, phosphate buffer $(\mathrm{pH}$ 6.9) and the tissue homogenate. The reaction mixtures were incubated at $37^{\circ} \mathrm{C}$ for $30 \mathrm{~min}$. DNS was added after incubation and kept in boiling water bath for $5 \mathrm{~min}$. After cooling, the reaction mixture was diluted with distilled water and absorbance was measured at $540 \mathrm{~nm}$. Maltose was used as the standard. Amylase activity was expressed as amole of maltose released from starch per min at $37^{\circ} \mathrm{C}$ temperature.

The Carbonic anhydrase activity was assayed by the method of (Wilbur and Anderson, 1948), with slight modifications. The total $3 \mathrm{ml}$ of the reaction mixture comprised of 2.9 $\mathrm{ml}$ of $15 \mathrm{mM}$ Tris-sulphate buffer ( $\mathrm{pH} 7.6$ ), $1 \mathrm{ml}$ of thesubstrate (PNPA- para-nitrophenol acetate) and $0.1 \mathrm{ml}$ of tissue homogenate. The reaction was started by addition of substrate and immediate mixing by inversion. The increase in OD was recorded at $348 \mathrm{~nm}$ at the $30 \mathrm{sec}$ interval. The enzymatic activity was expressed as unit's mg protein $1 \mathrm{~min}^{-1}$ at $0^{\circ} \mathrm{C}$ where 1 unit will cause the $\mathrm{pH}$ of a $0.012 \mathrm{M}$ buffer to drop from 8.3 to 6.3 per minute at $0{ }^{\circ} \mathrm{C}$.

Calpain assay was performed by the method of (Ross and Schataz,1973). Calpain reagent was prepared by dissolving $4 \mathrm{mg} / \mathrm{ml}$ casein in $80 \mathrm{mM}$ trisbuffer ( $\mathrm{pH} 7.5$ ) along with $5 \mathrm{mM}$ cysteine, $5 \mathrm{mM} \mathrm{CaCl} 2$ and $100 \mathrm{ml}$ of 2 mercapto ethanol (BME) was prepared and $\mathrm{pH}$ was adjusted to 7.5 after that autoclaved at $121^{\circ} \mathrm{C}$ and then cooled. $100 \mathrm{ml}$ of solution 4 $\mathrm{mg}$ casein dissolved by magnet stirrer at $30^{\circ} \mathrm{C}$ and filtered by $45 \mathrm{~mm}$ syringe filter. The test was carried out by adding $50 \mu \mathrm{l}$ sample to 100 $\mathrm{ml}$ of reagents and followed by incubation at $25^{\circ} \mathrm{C}$ for $1 \mathrm{hr}$. Than $1 \mathrm{ml} 5 \%$ TCA was added and mixed well and test tube kept on ice for 
$10 \mathrm{~min}$, centrifuged at $16000 \mathrm{rpm}$ for $20 \mathrm{~min}$ and supernatant was collected after centrifugation. Optical density (OD) is taken at $278 \mathrm{~nm}$. Blank is done with distilled water and control by theonly reagent without asample. One unit of calpain was defined as such quantities of anenzyme that increased the absorbance at $278 \mathrm{~nm}$ by 1.0 after $30 \mathrm{~min}$. of incubation at $25^{\circ} \mathrm{C}$. The final enzyme activity is calculated by subtracting the test absorbance to control and expressed enzyme activity.

Aspartate Amino Transferase (AST) activity was assayed in different tissue homogenates as described by Wooten (1964). The substrate comprised of 0.2 M DL- aspartic acid and 2 $\mathrm{mM} \alpha$-ketoglutarate in $0.05 \mathrm{M}$ phosphate buffer ( $\mathrm{pH}$ 7.4). In the treatment and control tubes, $0.5 \mathrm{ml}$ of substrate was added. The reaction was started by adding $0.1 \mathrm{ml}$ of tissue homogenate in the treatment tube. The assay mixture was incubated at $37^{\circ} \mathrm{C}$ for 60 minutes. The reaction was terminated by adding $0.5 \mathrm{ml}$ of $1 \mathrm{mM} \mathrm{2,4-dinitrophenyl}$ hydrazine (DNPH). In the control tubes, the enzyme source was added after DNPH solution. The tubes were held at room temperature for 20 minutes with occasional shaking. Then $5 \mathrm{ml}$ of $0.4 \mathrm{ml} \mathrm{NaOH}$ solution was added and the contents were thoroughly mixed. After 10 minutes, the OD was recorded at $540 \mathrm{~nm}$ against blank. The AST activity was expressed as nanomoles oxaloacetate formed / mg protein / minute at $37^{\circ} \mathrm{C}$. The procedure adopted for the estimation of ALT activity was same as that for AST activity estimation except that the substrate comprised of $0.2 \mathrm{M} \mathrm{D}, \mathrm{L}$ - alanine instead of aspartic acid. The ALT activity was expressed as nanomoles pyruvate formed / $\mathrm{mg}$ protein / minute at $37{ }^{\circ} \mathrm{C}$.

\section{Statistical analysis}

Statistical significance of difference was analysed using one-way analysis of variance (ANOVA) via SPSS 16.0. Duncan's multiple range test was used for post hoc comparison of mean $(\mathrm{p}<0.05)$. All data presented in the text, figures and tables are means \pm standard error and statistical significance for all statistical tests was set at $\mathrm{p}<0.05$.

\section{Results and Discussion}

\section{Growth performance and nutrient utilization}

Growth performance and nutrient utilization parameters are given in table 4 . The weight gain $\%$ was found to be significantly different $(\mathrm{P}<0.05)$ among the various treatment groups. Highest weight gain \% was recorded in T4 group (85.93 \pm 4.09$)$, and the lowest growth was recorded in the control group (61.21 \pm 4.01$)$. The value of SGR were varied significantly $\quad(\mathrm{P}<0.05)$ among different treatment groups. The lowest SGR value was found in control $(0.79 \pm 0.04)$ group and higher SGR was found in T4 group (1.03 \pm 0.04$)$. The FCR of different experimental groups were varied significantly $(\mathrm{P}<0.05)$. The lowest FCR $(1.60 \pm 0.05)$ was recorded in $\mathrm{T} 4$ group. The highest FCR was found in control $(2.06 \pm 0.11)$ group. The mean PER value was significantly different $(\mathrm{P}<0.05)$ among the different treatment groups. The highest PER value was recorded in T4 $(1.79 \pm 0.06)$ group. The lowest PER was recorded in control (1.39 \pm 0.07$)$.

\section{Enzyme assay}

The specific activity of amylase in the intestine of the fishes of different experimental groups is given in the table 5 . The highest amylase activity was found in the T4 (2.81 \pm 0.14$)$ group and lowest activity was recorded in control $(2.14 \pm 0.06)$ group. The amylase activity of intestine was significantly different among groups $(\mathrm{P}<0.05)$. The protease activity was highest in the $\mathrm{T} 4$ 
$(20.01 \pm 1.04)$ group and lowest inactivity in the control (17.20 \pm 0.31$)$ group. The protease activity in the intestine was found significant $(\mathrm{P}<0.05)$ among the different treatment groups. The activity of calpain in the muscle of the fishes of different experimental groups is given in table 5. The calpain activity of muscle was significantly different $(\mathrm{P}<0.05)$ among the different treatment groups. In the muscle, the calpain activity was found to be higher in the control $(0.44 \pm 0.03)$ group and lowest activity was recorded in FT5 $(0.29 \pm 0.01)$ group. The activity of carbonic anhydrase in the gill of the fishes of different experimental groups is shown in the table 5 . The activity of CA in the gill was significantly different $(\mathrm{P}<0.05)$ among the different treatment groups. In the gill, the CA activity was significantly higher $(23.97 \pm 0.57)$ in the T4 group and least activity was found in control $(11.20 \pm 0.40)$ group. The AST activity of $P$. hypophthalmus fingerlings fed with different experimental diet is given in table 6 . The activity of enzyme in muscle and liver were differed significantly $(\mathrm{P}<0.05)$. In fish muscle, the highest AST activity was found in control $(4.62 \pm 0.26)$ and lowest was found in $\mathrm{T} 3(1.71 \pm 0.10)$. In the liver, the highest activity was found in T2 $(3.72 \pm 0.12)$ and the lowest activity was found in control (1.42 \pm 0.06$)$. The ALT activity of $P$. hypophthalmus fingerlings fed with different experimental diets is given in table 6. The activity of enzyme in muscle and liver were differed significantly $(\mathrm{P}<0.05)$. In the muscle, the highest activity was found in T3 $(9.94 \pm 0.40)$ group which was significantly $(\mathrm{P}<0.05)$ different from other groups while lowest activity was found in T5 $(6.02 \pm 0.14)$ group. In the liver, the highest activity was found in control $(11.66 \pm 0.66)$ group and the lowest activity has been recorded in $\mathrm{T} 5$ (7.89 \pm 0.41$)$.

Zinc is one of the most important trace elements involved in animal growth, it is the most widely used metal co-factor of enzymes involved in protein, nucleic acid, carbohydrate and lipid metabolism as well as control of gene transcription and other fundamental biological processes. Shim and Lee (1993) reported that zinc deficient diet causes poor growth rate, low feed efficiency and high mortality in the guppy. Zinc deficient diet showed extremely low grow rate, high mortality, and the appearance of zinc deficiency symptoms such as a cataract in the eyes and erosion of the fins and skin in rainbow trout (Ogino and Yang, 1978). Dietary zinc concentration for rainbow trout was optimized as 15 to $30 \mathrm{ppm}$ for adequate growth rate, FCR, and tissue zinc concentration. In rainbow trout, zinc deficiency causes growth suppression, mortality, lenses cataract, erosion of fin and skin, and short-body dwarfism (Ogino and Yang, 1978; Satoh et al., 1983). Ogino et al., (1979) reported that dietary zinc level has a significant effect on appetite, growth rate, and mortality and also has a significant effect on the level of iron and copper in the tissues of common carp. The fish fed the diet containing 1 ppm zinc showed deficiency symptoms such as erosion of the skin and the fin. Minimum supplemental zinc level of 15-20 $\mathrm{mg} \mathrm{Zn} \mathrm{Kg}{ }^{-1}$ was recommended for carp diet to provide enough available Zinc for proper metabolism. Jeng and Sun (1981) determined the relationship between the dietary Zinc level and zinc concentration in common carp. Fishes were fed diets supplemented with 17, 294, 1,007 and 1,974 ppm Zinc. The highest growth rate was found at $17 \mathrm{ppm}$ zinc level but the zinc concentration in the tissue increased with increase in inclusion level of zinc to the diets. Brood stock diet low in zinc concentrations reduced egg production and hatchability in Rainbow trout (Takeuchi et al., 1981). In channel catfish, diets low in zinc concentration caused a reduction in growth rate, appetite, serum zinc concentration and bone zinc and calcium concentrations (Gatlin and Wilson, 1984). 
Ketola et al., (1981) quantified zinc requirements of juvenile grouper (Epinephelus malabaricus), fed with semipurified diet supplemented with the different inclusion of $\mathrm{ZnSO}_{4}$. Weight gain and feed efficiency were significantly lower in Grouper fed diet without zinc supplementation. Zinc concentrations in serum, muscle, vertebra, scale and zinc metallo enzyme superoxide dismutase concentration in red blood cell were affected by the supplemented zinc level.

The dietary zinc requirement of the juvenile grouper was recommended $28-36 \mathrm{mg} \mathrm{Zn} \mathrm{Kg}^{-1}$ diets. Park et al., (1989) determined the effect of $\mathrm{Zn}$ supplementation to fish meal diets on growth of Anguilla japonica (Japanese eel). Fish on diet supplemented with 50-200 $\mu \mathrm{g} \mathrm{g}^{-1}$ level of $\mathrm{Zn}$ were observed to have the high values of average body weight and feed efficiency. Eel fed without supplementation of $\mathrm{Zn}$ caused a high value of condition factor and lower concentration of zinc in bone. Gatlin et al., (1991) determined the dietary Zinc requirement of Red drum (Sciaenopso cellatus). A semi-purified diet containing graded levels of zinc $(5,10,20,30$, and 450 $\mathrm{mg} \mathrm{Zn} \mathrm{kg}{ }^{-1}$ was fed to the juvenile red drum.

Minimum dietary zinc requirement of red drum was optimized at $20-25 \mathrm{mg} \mathrm{Zn} \mathrm{kg}{ }^{-1}$ of dry diet on the basis of gain, feed efficiency, and survival and scale Zinc concentration etc. Dietary zinc requirement for Nile tilapia (Oreochrom uniloticus) was studied by Eid et al., (1993), Nile tilapia fed with the basal diet containing $1 \mathrm{mg} \quad \mathrm{Zn} \quad \mathrm{Kg}^{-1}$ developed deficiency symptom such as anorexia, reduced growth, and high mortality while those fed the diet containing the level over 30 mg $\mathrm{Zn} \mathrm{Kg}^{-1}$ showed reduced mortality and improved growth.

As present study minimum, dietary zinc requirement for Nile tilapia was recommended to be $25-30 \mathrm{mg} \mathrm{Zn} \mathrm{Kg}^{-1}$. Maage et al., (2001) studied on the zinc status of juvenile Atlantic salmon (Salmon salar) when fed abasal diet containing $17 \mathrm{mg} \mathrm{Zn} \mathrm{Kg}^{-1}$ or $80 \mathrm{mg} \mathrm{Zn} \mathrm{Kg}{ }^{-1} \operatorname{diet}\left(\mathrm{ZnSO}_{4} .7 \mathrm{H}_{2} \mathrm{O}\right)$.

Whole body zinc status was determined by measuring $\mathrm{Zn}$ concentration in different tissue (liver, kidney, intestine, and vertebra) level of zinc and serum alkaline phosphates activity. It was found that there were no significant differences in growth due to different dietary zinc concentration. Zn-deficient diet did not cause retarded growth, feed efficiency and survival in channel catfish (Li et al., 1996).

Carmoe Sa et al., (2004) studied on optimum Zinc supplementation level in Nile tilapia (Oreochromis niloticus) juveniles by using vegetable-based diets supplemented with different level of zinc $\left(\mathrm{ZnSO}_{4} \bullet \mathrm{H}_{2} \mathrm{O}\right)$. Highest weight gain and bone zinc concentration was obtained in 44.50 and $79.51 \mathrm{mg} \mathrm{Zn} \mathrm{Kg}^{-1}$ diet respectively.

But when fishes were challenged by a zincdeficient diet, it mobilized stored bone zinc to preserve zinc status. By considering the bone zinc saturation $79.51 \mathrm{mg} \mathrm{Kg}^{-1}$ diet was recommended to be optimum dietary zinc supplementation $\left(\mathrm{ZnSO}_{4} \cdot \mathrm{H}_{2} \mathrm{O}\right)$ in vegetablebased diets to Nile tilapia.

In the present study, the different zinc level supplemented diets were showed a significant effect on weight gain percentage. 
Table.1 Composition of purified experimental diets

\begin{tabular}{|c|c|c|c|c|c|c|}
\hline Ingredients & Control & T1 & $\mathbf{T 2}$ & T3 & T4 & T5 \\
\hline Casein, Purified (g) & 25.5 & 25.5 & 25.5 & 25.5 & 25.5 & 25.5 \\
\hline Gelatin (g) & 8.5 & 8.5 & 8.5 & 8.5 & 8.5 & 8.5 \\
\hline Dextrin $(g)$ & 10 & 10 & 10 & 10 & 10 & 10 \\
\hline Starch soluble (g) & 30 & 30 & 30 & 30 & 30 & 30 \\
\hline Cellulose $(\mathrm{g})$ & 13.603 & 13.602 & 13.602 & 13.602 & 13.601 & 13.601 \\
\hline CMC (g) & 2 & 2 & 2 & 2 & 2 & 2 \\
\hline Sunflower oil (g) & 4 & 4 & 4 & 4 & 4 & 4 \\
\hline Cod Liver oil (g) & 4 & 4 & 4 & 4 & 4 & 4 \\
\hline Vitamin-Mineral Mix(Zinc (g) & 2 & 2 & 2 & 2 & 2 & 2 \\
\hline Vitamin C (g) & 0.1 & 0.1 & 0.1 & 0.1 & 0.1 & 0.1 \\
\hline Betaine Hydrochloride (g) & 0.275 & 0.275 & 0.275 & 0.275 & 0.275 & 0.275 \\
\hline $\operatorname{BHT}(g)$ & 0.02 & 0.02 & 0.02 & 0.02 & 0.02 & 0.02 \\
\hline Zincsulphate(g) & 0.002 & 0.0023 & 0.0026 & 0.0029 & 0.0032 & 0.0035 \\
\hline Total & 100 & 100 & 100 & 100 & 100 & 100 \\
\hline
\end{tabular}

Procured from HIMEDIA (JTJ Enterprises, Mumbai, India), Prepared manually and all components from HI media Ltd, SD Fine Chemicals Ltd. India. Composition of vitamin mineral mix (quantity/250g starch powder) : Vitamin A-55,00,00 IU; Vitamin D3-11,00,00 IU; Vitamin B1-20mg; Vitamin B2-200mg; Vitamin E-75mg; Vitamin K100mg; Vitamin B12-0.6mcg; Calcium pantothenate-250mg; Nicotinamide-1000mg; Pyridoxine-100mg; Mn-2700mg; I-100mg; Fe-750mg; Choline chloride-500mg; Cu200mg; Co-45mg; Ca-50g; P-30g; Se-0.5ppm. 
Int.J.Curr.Microbiol.App.Sci (2017) 6(6): 671-683

Table.2 Proximate composition (\% DM basis) of the different experimental diets

\begin{tabular}{ccccccc}
\hline Treatments & $\mathbf{C}$ & $\mathbf{T 1}$ & $\mathbf{T 2}$ & $\mathbf{T 3}$ & $\mathbf{T 4}$ & $\mathbf{T 5}$ \\
\hline Moisture & $11.10 \pm 0.05$ & $11.15 \pm 0.06$ & $11.09 \pm 0.24$ & $11.03 \pm 0.01$ & $10.51 \pm 0.19$ & $10.69 \pm 0.19$ \\
DM & $88.90 \pm 0.5$ & $88.85 \pm 0.06$ & $88.91 \pm 0.24$ & $88.97 \pm 0.01$ & $89.49 \pm 0.19$ & $89.31 \pm 0.19$ \\
CP & $32.13 \pm 0.10$ & $31.93 \pm 0.00$ & $31.35 \pm 0.68$ & $31.92 \pm 0.16$ & $31.84 \pm 0.64$ & $31.76 \pm 0.52$ \\
EE & $6.13 \pm 0.12$ & $6.14 \pm 0.13$ & $6.03 \pm 0.20$ & $6.05 \pm 0.29$ & $6.04 \pm 0.40$ & $6.21 \pm 0.40$ \\
Ash & $1.34 \pm 0.01$ & $1.34 \pm 0.05$ & $1.34 \pm 0.00$ & $1.35 \pm 0.01$ & $1.36 \pm 0.02$ & $1.35 \pm 0.01$ \\
TC & $49.29 \pm 0.07$ & $49.45 \pm 0.12$ & $50.20 \pm 1.06$ & $49.65 \pm 0.32$ & $50.26 \pm 0.96$ & $49.99 \pm 0.78$ \\
DE* & $381.00 \pm 0.45$ & $381.00 \pm 0.69$ & $380.00 \pm 0.19$ & $381.00 \pm 1.50$ & $383.00 \pm 2.21$ & $383.00 \pm 2.64$ \\
\hline
\end{tabular}

Data expressed as Mean \pm SE $n=3$; Calculated Digestible Energy*(K cal/ 100g) $=(\%$ CP 4) + (\% EE 9) + (\% TC 4) (Halver, 1976). DM=Dry matter; $\mathrm{EE}=$ Ether Extract; $\mathrm{TC}=$ Total Carbohydrate; $\mathrm{CP}=$ crude protein; $\mathrm{DE}^{*}=$ Digestible Energy.

Table.3 Proximate composition of the whole body of different experimental groups (\% DM basis)

\begin{tabular}{ccccccc}
\hline Treatments & C & T1 & T2 & T3 & T4 & T5 \\
\hline Moisture & $74.59 \pm 0.59$ & $75.63 \pm 0.62$ & $75.69 \pm 0.43$ & $75.53 \pm 0.94$ & $76.66 \pm 0.13$ & $74.82 \pm 0.42$ \\
OM & $25.41 \pm 0.59$ & $24.37 \pm 0.62$ & $24.31 \pm 0.43$ & $24.47 \pm 0.94$ & $23.34 \pm 0.13$ & $25.18 \pm 0.42$ \\
CP & $67.43 \pm 0.62$ & $66.13 \pm 1.44$ & $68.30 \pm 0.40$ & $67.20 \pm 1.07$ & $66.73 \pm 2.23$ & $66.73 \pm 0.23$ \\
TC & $9.87 \pm 1.31$ & $10.52 \pm 1.36$ & $9.25 \pm 0.44$ & $9.59 \pm 0.98$ & $10.31 \pm 1.08$ & $9.31 \pm 0.35$ \\
EE & $14.33 \pm 0.32$ & $14.52 \pm 0.56$ & $14.19 \pm 0.39$ & $14.15 \pm 0.26$ & $14.22 \pm 1.69$ & $14.79 \pm 0.55$ \\
Ash & $8.37 \pm 0.38$ & $8.83 \pm 0.48$ & $8.27 \pm 0.33$ & $9.07 \pm 0.15$ & $8.73 \pm 0.65$ & $9.17 \pm 0.77$ \\
\hline
\end{tabular}

Data expressed as Mean $\pm \mathrm{SE}, \mathrm{n}=3$

$\mathrm{DM}=$ Dry matter; $\mathrm{OM}=$ Organic matter; $\mathrm{EE}=$ Ether Extract; $\mathrm{TC}=$ Total Carbohydrate; $\mathrm{CP}=$ crude protein.

Table.4 Growth parameters (\% wt. gain, FCR, PER, SGR) of different treatment groups

\begin{tabular}{|c|c|c|c|c|c|c|c|}
\hline Treatments & $\mathrm{C}$ & $\mathrm{T} 1$ & $\mathrm{~T} 2$ & $\mathrm{~T} 3$ & $\mathrm{~T} 4$ & $\mathrm{~T} 5$ & p-Value \\
\hline$\%$ wt. gain & $61.21^{\mathrm{b}}{ }_{ \pm} 4.01$ & $72.90^{\mathrm{ab}}{ }_{ \pm} 5.73$ & $75.27^{\mathrm{bc}} 2.48$ & $77.77_{ \pm}^{\mathrm{bc}}{ }_{ \pm} .54$ & $85.93^{\mathrm{c}} 4.09$ & $76.89^{\mathrm{bc}}{ }_{ \pm} 3.15$ & 0.016 \\
\hline FCR & $2.06_{ \pm}^{\mathrm{b}}{ }_{ \pm} 0.11$ & $1.81^{\mathrm{a}}{ }_{ \pm} 0.11$ & $1.76_{ \pm}^{\mathrm{a}}{ }_{ \pm} 0.01$ & $1.72^{\mathrm{a}}{ }_{ \pm} 0.06$ & $1.60_{ \pm}^{\mathrm{a}}{ }_{ \pm} 0.05$ & $1.73^{\mathrm{a}}{ }_{ \pm} 0.05$ & 0.018 \\
\hline PER & $1.39^{\mathrm{a}}{ }_{ \pm} 0.07$ & $1.59^{\mathrm{b}}{ }_{ \pm} 0.09$ & $1.63^{\mathrm{b}}{ }_{ \pm} 0.01$ & $1.67^{\mathrm{b}}{ }_{ \pm} 0.06$ & $1.79^{\mathrm{b}}{ }_{ \pm} 0.06$ & $1.65^{\mathrm{b}}{ }_{ \pm} 0.05$ & 0.016 \\
\hline SGR & $0.79^{\mathrm{a}}{ }_{ \pm} 0.04$ & $0.91^{\mathrm{b}}{ }_{ \pm} 0.06$ & $0.94^{\mathrm{b}}{ }_{ \pm} 0.01$ & $0.96^{\mathrm{b}}{ }_{ \pm} 0.03$ & $1.03^{\mathrm{b}}{ }_{ \pm} 0.04$ & $0.95^{\mathrm{b}}{ }_{ \pm} 0.03$ & 0.016 \\
\hline
\end{tabular}

Data expressed as Mean \pm SE, $n-3$; Mean values in the same row with different superscript differ significantly $(\mathrm{P}<0.05)$, SGRSpecific Growth Rate, FCR- Feed Conversion Ratio, PER- Protein Efficiency Ratio.

Table.5 Amylase, Protease (IU/mg protein), Calpain and Carbonic anhydrase (U/min/mg protein) activity activities of different experimental groups fed graded level of dietary Zinc

\begin{tabular}{ccccc}
\hline Treatments & Amylase (Intestine) & Protease (Intestine) & Calpain (Muscle) & CA (Gill) \\
\hline Control & $2.14^{\mathrm{a}} \pm 0.06$ & $18.71^{\mathrm{abc}} \pm 0.61$ & $0.44^{\mathrm{c}} \pm 0.03$ & $11.20^{\mathrm{a}} \pm 0.40$ \\
T1 & $2.47^{\mathrm{b}} \pm 0.07$ & $19.09^{\mathrm{b}} \pm 0.44$ & $0.42^{\mathrm{c}} \pm 0.01$ & $14.47^{\mathrm{b}} \pm 0.58$ \\
T2 & $2.24^{\mathrm{a}} \pm 0.04$ & $17.20^{\mathrm{a}} \pm 0.31$ & $0.40^{\mathrm{c}} \pm 0.02$ & $15.11^{\mathrm{b}} \pm 0.33$ \\
T3 & $2.51^{\mathrm{b}} \pm 0.06$ & $18.15^{\mathrm{a}} \pm 0.18$ & $0.38^{\mathrm{bc}} \pm 0.02$ & $22.77^{\mathrm{c}} \pm 0.43$ \\
T4 & $2.81^{\mathrm{bc}} \pm 0.14$ & $20.01^{\mathrm{c}} \pm 1.04$ & $0.32^{\mathrm{ab}} \pm 0.03$ & $23.97^{\mathrm{c}} \pm 0.57$ \\
T5 & $2.66^{\mathrm{c}} \pm 0.04$ & $19.10^{\mathrm{bc}} \pm 0.36$ & $0.29^{\mathrm{a}} \pm 0.01$ & $23.50^{\mathrm{c}} \pm 0.23$ \\
P-Value & 0.001 & 0.03 & 0.001 & 0.001 \\
\hline
\end{tabular}

Data expressed as Mean $\pm \mathrm{SE} n=3$, Mean values in the same column with different superscript differ significantly $(\mathrm{P}<0.05)$. Amylase activity is expressed as micromole of maltose released/min/mg protein Protease activity is expressed as micromole of tyrosine $\mathrm{released} / \mathrm{min} / \mathrm{mg}$ protein. 
Table.6 AST and ALT activity in the muscle and liver of different experimental group

\begin{tabular}{ccccc}
\hline Treatments & AST (MUSCLE) & AST (LIVER) & ALT (MUSCLE) & ALT (LIVER) \\
\hline Control & $4.62^{\mathrm{d}} \pm 0.26$ & $1.42^{\mathrm{a}} \pm 0.06$ & $7.70^{\mathrm{b}} \pm 0.33$ & $11.66^{\mathrm{c}} \pm 0.66$ \\
T1 & $3.86^{\mathrm{c}} \pm 0.20$ & $2.41^{\mathrm{b}} \pm 0.16$ & $9.88^{\mathrm{d}} \pm 0.08$ & $10.86^{\mathrm{bc}} \pm 0.37$ \\
T2 & $3.27^{\mathrm{b}} \pm 0.13$ & $3.72^{\mathrm{c}} \pm 0.12$ & $9.91^{\mathrm{e}} \pm 0.34$ & $11.61^{\mathrm{c}} \pm 0.71$ \\
T3 & $1.71^{\mathrm{a}} \pm 0.10$ & $3.37^{\mathrm{c}} \pm 0.16$ & $9.94^{\mathrm{d}} \pm 0.40$ & $10.11^{\mathrm{b}} \pm 0.15$ \\
T4 & $1.85^{\mathrm{a}} \pm 0.17$ & $3.42^{\mathrm{c}} \pm 0.12$ & $8.78^{\mathrm{c}} \pm 0.31$ & $11.52^{\mathrm{bc}} \pm 0.26$ \\
T5 & $1.81^{\mathrm{a}} \pm 0.08$ & $3.38^{\mathrm{c}} \pm 0.16$ & $6.02^{\mathrm{a}} \pm 0.14$ & $7.89^{\mathrm{a}} \pm 0.41$ \\
P-Value & 0.001 & 0.001 & 0.001 & 0.001 \\
\hline
\end{tabular}

Data expressed as mean $\pm \mathrm{SE}, \mathrm{n}=6$. Mean values bearing different superscripts under each column vary significantly $(\mathrm{P}<0.05)$. AST: specific activities expressed as nano moles of oxaloacetate released $/ \mathrm{min} / \mathrm{mg}$ protein at $37^{\circ} \mathrm{C}$. Data expressed as mean $\pm \mathrm{SE}$, $\mathrm{n}=6$. ALT: specific activities expressed as nano moles of sodium pyruvate formed $/ \mathrm{mg}$ protein $/$ minute at $37^{\circ} \mathrm{C}$.

Inclusion level of $32 \mathrm{mg} / \mathrm{kg}$ of zinc show ad maximum SGR compared to control as well as the other group. this may be correlated with the fact that $32 \mathrm{mg} / \mathrm{kg}$ or below supplemented zinc were better utilized by $P$. hypophthalmus while the higher inclusion level reflected the reduced growth and the tissue accumulation of the zinc were reflected in the T5 group with the supplementation of $35 \mathrm{mg} / \mathrm{kg}$.

The lowest weight gain percentage was in control group and growth improvements observed in the dietary zinc supplemented at levels of $23 \mathrm{mg} / \mathrm{kg}, 26 \mathrm{mg} / \mathrm{kg}, 29 \mathrm{mg} / \mathrm{kg}$ and maximum in $32 \mathrm{mg} / \mathrm{kg}$ supplemented. However, growth retardation has been encountered inT5 $(35 \mathrm{mg} / \mathrm{kg})$ group. It clearly indicates that increase in the level of zinc sulphate negatively effect on growth. Dietary zinc supplemented diet $(35 \mathrm{mg} / \mathrm{kg})$ can be considered as more than adequate level of zinc, which did not have a significant effect on growth. This result is supported by (Jeng and Sun, 1981) who reported that after certain dietary level of zinc supplementation, the growth was not improved in common carp. Similarly Ogino and Yong (1978) reported that zinc deficiency induced retarded growth and high mortality in common carp. The value of the PER and SGR was found in the same trend as specific growth and the correlation holds the support for each other. This result is supported by (Shimand Lee, 1993), whore ported better growth, lower
FCR and higher FCE in Guppy fed with different inclusion of Zinc in the diets. Eid et al., (1993) reported that Zinc deficient diet show higher FCR and lower growth rate in Oreochromis niloticus. So, the present study indicated that dietary zinc supplementation up to $32 \mathrm{mg} / \mathrm{kg}$ diet has a direct influence on FCR of Pangasianodon hypophthalmus.

Calpains (EC 3.4.22.17) or $\mathrm{Ca}^{2+}$-dependent are distributed ubiquitously throughout the animal kingdom. Traditionally, two calpainiso forms have been identified; micro $(\mu-)$ calpain and milli (m-) calpain, which are activated at micromolar and millimolar calcium concentrations, respectively. As with most other regulated proteases calpain enzymes have an endogenous inhibitor known as calpastatin. The calpains and calpastatin constitute the calpain system, a major proteolytic system responsible for regulating initiation of myofibrillar protein degradation that can result in antemortem muscle atrophy nd post-mortem meat tenderization (Goll et al., 1983, Koohmaraie, 1988, 1990). Extension of post-mortem storage leads to an improvement in meat tenderness. It is generally agreed that proteolysis of key myofibrillar proteins is the major contributor to the increased tenderness observed during post-mortem storage (Goll et al., 1983, Koohmaraie, 1988, 1992a, b). In the present study, the activity of calpain in the muscle of the fishes of different experimental groups 
was shown the significant relation with Zinc. The calpain activity of muscle was significantly different $(\mathrm{P}<0.05)$. In the muscle, the calpain activity was found to be higher in the control $(0.44 \pm 0.03)$ group and lowest activity was recorded in T5 $(0.29 \pm 0.01)$ group the result was supported by increasing Zinc concentration is inversely proportional to absorption of calcium hence the activity of calpain might be reduced and favour better texture was found at the highest Zinc supplementation level.

Carbonic an hydrases catalyse the rapid inter conversion of carbon dioxide and bicarbonate to maintain acid-base balance in blood and other tissues and to help transport carbon dioxide out of tissues. The enzyme stabilizes the muscle $\mathrm{pH}$ and the muscle performance and sustained energy production is ensured. The main function of $\mathrm{CA}$ is to facilitate the transport of $\mathrm{CO}_{2}$ into the capillaries by hydrating at the capillary wall and thus maintaining the concentration gradient of $\mathrm{CO}_{2}$ between the muscle and the blood. In vertebrates, this role appears to be small at rest but becomes more important as the $\mathrm{CO} 2$ load within muscle increases, such as during exercise (Geers and Gros, 2000). The main role of cytoplasmic $\mathrm{CA}$ is to provide counter ions for transport processes involved with ion regulation and $\mathrm{pH}$ balance (Marshall, 2002, Evans et al., 2005). Thus, the primary role of cytoplasmic CA activity in teleost gills is not $\mathrm{CO}_{2}$ excretion. The activities of carbonic anhydrase in the gill of the fishes of different experimental groups in the present study are in strong correlation. The activity of $\mathrm{CA}$ in the gill was significantly different $(\mathrm{P}<0.05)$ among the different treatment groups. In the gill, the CA activity was significantly higher $(23.97 \pm 0.57)$ in the T4 group and least activity was found in control $(11.20 \pm 0.40)$ group. In present study maximum growth and nutrient utilization of Pangasianodon hypophthalmus fingerlings were achieved at dietary zinc supplementation of $32 \mathrm{mg} \mathrm{kg}^{-1}$. Since the size of fish selected for present experiment were small and experiments were conducted in laboratory condition, further experiments with longer culture period and bigger size fish are essential to utilize the findings of this study which can be used for commercial farming of P.hypophthalmus.

\section{Acknowledgements}

Authors sincerely acknowledge the Indian council of Agriculture Research New Delhi for providing financial support to conduct this study. Authors are also thankful to Director, Central Institute of Fisheries Education, Mumbai, India for making all arrangement for successful completion of the research.

\section{References}

Ahmad, N., Hasan, M.R. 2007. Sustainable livelihoods of pangus farming in rural Bangladesh. Aquaculture Asia Magazine, 12(4): 5-10.

APHA-AWWA-WEF. $1998 . \quad$ Standard methods for the estimation of water and waste water, $20^{\text {th }}$ edn. (Ed. Clesceri, L. S., Greenberg, A.E., Eaton, A.D). American Public Health Association, American Water Works Association, Water Environment Federation, Washington, DC.

Carmoe SA, M.V., Do, Pezzato, L.E., Barros, M.M., De, M.P.P. 2004. Optimum zinc supplementation level in Nile tilapia, Oreochromis niloticus juvenile diets. Aquaculture, 238: 385-401.

Chattopadhyay, N.R., Mazumdar, B. 2002. Induced spawning of Pangasiussutchi with pituitary extract. Aquaculture Asia, 7: 43-44.

Chen, D., Pet, E. 2001. Zinc requirement in Nile tilapia. J. World Aquacult. Soc., 26: 347-355. 
Drapean, G. 1976. Protease from Staphylococcus aureus. Methods in Enzymology (ed.) B, L. Lorand, Academic Press, New York, 469 pp.

Eid, A.E., Ghonim, S.I. 1993. Deitary zinc requirement of fingerling of Oreochromis niloticous. Aquaculture, 119: 259-264.

Evans, D.H., Piermarini, P.M., Choe, K.P. 2005. The multifunctional fish gill: dominant site of gas exchange, osmoregulation, acid-base regulation, and excretion of nitrogenous waste. Physiol. Rev., 85(1): 97-177.

Gatlin, D.M., Connell, J.P.O., Scarpa, J. 1991. Dietary zinc requirement of the red drum (Sciaenops ocellatus). Aquaculture, 92: 259-265.

Gatlin, D.M., III Phillips, H.F., Torrans, E.L. 1989. Effects of various levels of dietary copper and zinc on channel catfish. Aquaculture, 76: 127-134.

Gatlin, D.M., III Wilson, R.P. 1984. Zinc supplementation of practical channel catfish diets. Aquaculture, 41: 31-36.

Geers, C., Gros, G. 2000. Carbon dioxide transport and carbonic anhydrase in blood and muscle. Physiol. Rev., 80(2): 681-715.

Goll, D.E., Otsuka, Y., Nagainis, P.A., Shannon, J.D., Sathe, S.K., Muguruma, M. 1983. Role of muscle proteinases in maintenance of muscle integrity and mass. J. Food Biochem., 7: 137-177.

Halver, J.E. 1976. The nutritional requirements of cultivated warmwater and coldwater fish species. Paper No. 31. FAO Technical Conference on Aquaculture, Kyoto, 26 May-2 June, $1976.9 \mathrm{pp}$.

Hasting, W.H. 1967. Progress in sport fisheries research, 1966: feed formulation, physical quality of pelleted feed; digestibility. Fish Wildl. Serv. (U.S.) Res. Publ., 39: 137-141.
Hung, L.T., Suhenda, N., Slembrouck, J., Lazard, J., Moreau, Y. 2004. Comparison of dietary protein and energy utilization in three Asian catfish (Pangasius bocourti, Pangasius hypophthalmus and Pangasius djambal). Aquaculture Nutri., 10: 317326.

Hung, L.T., Liem, P.T., Hu, H.T., Mariojouls, C. 2002. Comparing growth and protein requirement for fingerlings of three catfish of the Mekong River (Pangasius bocourti, $P$. hypophthalmus and $P$. conchophilus). J. Aquaculture in the Tropics, 17(4): 325-335

Jeng, S.S., Sun, L.T. 1981. Effects of dietary zinc levels on zinc concentrations in tissues of common carp. Jr. Nutr., 111: 134-140.

Ketola, H.G. 1981. Dietary zinc requirement of juvenile grouper (Epinephelus malabaricus). Jr. Nutr., 111: 435-443.

Koohmaraie, M. 1988. The role of endogenous proteases in meat tenderness. Rec. Meat Conf. Proc., 41: 89-100.

Koohmaraie, M. 1990. Inhibition of postmortem tenderization in ovine carcasses through infusion of zinc. J. Anim. Sci., 68: 1476-1483.

Koohmaraie, M. 1992a. Role of the neutral proteinases in postmortem muscle protein degradation and meat tenderness. Rec. Meat Conf. Proc., 45: 63-100.

Koohmaraie, M. 1992b. The role of $\mathrm{Ca} 2+-$ dependent proteases (calpains) in post mortem proteolysis and meat tenderness. Biochem., 74: 239-245.

Lall, S.P. 2002. The minerals. Fish Nutr., 3: 259-308.

Li, M.H., and Robinson, E.H. 1996. Comparison of chelated zinc and zinc sulfate as zinc sources for growth and bone mineralization of channel catfish 
(Ictalurus punctatus) fed practical diets. Aquaculture, 146(3): 237-243.

Maage, A., Julshamn, K. 1993. Assessment of zinc status in juvenile Atlantic salmon, Salmosalar by measurement of whole body and tissue levels of zinc. Aquaculture, 117: 179-191.

Maage, A., Julshamn, K., Gerd, E.B. 2001. Zinc gluconate and zinc sulphate as dietary zinc sources for Atlantic salmon. Aqua. Nutr., 7: 183-187.

Marshall, W.S. 2002. $\mathrm{Na}+, \mathrm{Cl}-, \mathrm{Ca} 2+$ and $\mathrm{Zn} 2+$ transport by fish gills: retrospective review and prospective synthesis. J. Experimental Zool., 293(3): 264-283.

Ogino, C., Yang, G.Y. 1978. Requirement of rainbow trout for dietary zinc. Bull. Jpn. Soc. Sci. Fish, 44: 1015-1018.

Ogino, C., Yang, G.Y. 1979. Requirement of carp for dietary zinc. Bull. Jpn. Soc. Sci. Fish, 45: 967-969.

Park, C.W., Shimizu, C. 1989. Suitable level of zinc supplementation to the formulated diets in young eel. Nippon Suisan Gakkaishi, 55: 2137-2141.

Rick, W., Stegbauer, H.P. 1974. Amylase measurement of reducing groups. In: Methods of Enzymatic Analysis (ed.
Bergmeyer, H.V.), 2ndedn, Vol. 2, Academic Press, and New York. Pp. 885-889.

Ross, E., Schatz, G. 1973. Assay of protein in the presence of high concentrations of sulfhydryl compounds. Anal. Biochem., 54: 304-306.

Shim, K.F., Lee, T.L. 1993. Zinc requirements of the guppy (Poeciliareticulata peters). J. Aquac. Trop., 8: 81-90.

Takeuchi, T., Watanabe, T., Ogino, C., Satio, M., Nishimura K., Nose, T., 1981. Effects of low protein-high calorie diets and deletion of trace elements from a fishmeal diet on reproduction of rainbow trout. Bull. Jpn. Soc. Sci. Fish, 47: 645-654.

Wekell, J.C., Shearer, K.D., Houle, C.R. 1983. High zinc supplementation of rainbow trout diets. Prog. Fish Cult., 45(3): 144-147.

Wilbur, K.M., Anderson, N.G., 1948. Electrometric and colorimetric determination of carbonic anhydrase. $J$. Biol. Chem., 176: 147-154.

Wooten, I.D.P. 1964. Microanalysis in Medical Biochemistry, 4th edn., J and Churchill Ltd, London, 101-107.

\section{How to cite this article:}

Dilip Kumar Singh, Mukesh Kumar, Amit Ranjan, Uday Kumar Udit, Bhartendu Vimal, Binay Bhushan Nayak and Subodh Gupta. 2017. Growth and nutrient utilization of Pangasianodon hypophthalmus (Sauvage, 1878) fed with graded level of Zinc. Int.J.Curr.Microbiol.App.Sci. 6(6): 671-683. doi: https://doi.org/10.20546/ijcmas.2017.606.079 